\title{
TANGGAP COVID-19 \\ UNTUK MENINGKATKAN KESEHATAN MASYARAKAT DESA KLIWONAN, GRABAG, MAGELANG
}

\author{
Wahyudi $^{1}$, Salsabila Resaputri Mulyono \\ ${ }^{1}$ Universitas Sebelas Maret \\ ${ }^{2}$ Universitas sebelas Maret
}

wahyudi@fkip.uns.ac.id, salsaresaputri@student.uns.ac.id

\begin{abstract}
Abstrak
Berbagai peraturan, himbauan, dan edukasi tentang Covid-19 telah disampaikan oleh pemerintah, tenaga kesehatan, dan pihak-pihak yang terkait kepada masyarakat sebagai langkah pencegahan penularan Covid-19. Namun demikian, masih banyak masyarakat yang belum memahami, bahkan masih banyak yang melakukan pelanggaran. Untuk itu tujuan kegiatan Pengabdian kepada Masyarakat ini adalah: (1) meningkatkan pengetahuan serta pemahaman masyarakat mengenai bahaya dan penularan Covid-19, (2) meningkatkan kesadaran masyarakat mengenai tindakan promotif dan preventif sebagai upaya memutus mata rantai penularan Covid-19, (3) meningkatkan kesadaran masyarakat terhadap perilaku hidup bersih dan sehat (PHBS).

Kegiatan ini dilaksanakan di wilayah RT 05/RW 02, Kliwonan II, Grabag, Kabupaten Magelang menggunakan metode sosialisasi dan edukasi secara daring dan tatap muka dengan memperhatikan protokol kesehatan yang berlaku dengan menggunakan pendekatan masyarakat mezzo dan makro. Hasil kegiatan pengabdian kepada masyarakat adalah (1) peningkatan pengetahuan serta pemahaman masyarakat mengenai bahaya dan penularan Covid-19, (2) peningkatan kesadaran masyarakat mengenai tindakan promotif dan preventif sebagai upaya memutus mata rantai penularan Covid-19, (3) peningkatan kesadaran masyarakat terhadap perilaku hidup bersih dan sehat. Dengan hasil kegiatan tersebut, maka dapat disimpulkan bahwa masyarakat dapat meningkatkan pengetahuan dan pemahaman tentang Covid-19 dan dapat menerapkannya dalam kehidpan sehari-hari untuk memutus mata rantai penularan Covid-19.
\end{abstract}

Kata Kunci : Covid-19, Kesehatan Masyarakat

\section{PENDAHULUAN}

Saat ini Covid-19 menjadi pandemi di seluruh dunia yang menimbulkan berbagai dampak pada sektor kesehatan, sosial, dan ekonomi. Corona virus disease 2019 atau Covid-19 merupakan penyakit saluran pernapasan yang disebabkan oleh virus SARS-CoV-2 (Li et al, 2020). Covid-19 awalnya muncul di Kota Wuhan, Provinsi Hubei, China pada akhir tahun 2019 kemudian mulai menyebar ke seluruh dunia hingga World Health Organization (WHO) mendeklarasikan Covid-19 sebagai pandemi pada 11 Maret 2020 (WHO, 2020). Hingga 9 Maret 2020, WHO telah mencatat jumlah kasus Covid-19 di seluruh dunia sebesar 3.885.812 kasus dengan 265.862 kematian. Di Indonesia sendiri didapatkan 13.112 kasus dengan total kematian sebesar 943 (WHO, 2020). Karena jumlah yang terus bertambah, pemerintah Indonesia mulai bertindak dengan menetapkan status Kejadian Luar Biasa (KLB) mulai bulan Maret 2020 dan memberlakukan aturan Pembatasan Sosial Berskala

Kesehatan 
Besar (PSBB) di beberapa wilayah pada bulan April 2020.

Corona virus disease 2019 atau Covid-19 merupakan penyakit saluran pernapasan yang disebabkan oleh virus SARS-CoV-2. Covid-19 menyebar melalui droplet dari penderita. Penyakit ini memiliki gejala umum seperti demam, sakit tenggorokan, rasa lelah (malaise), sesak, dan batuk kering. Gejala yang dialami biasanya bersifat ringan dan muncul secara bertahap, bahkan pada beberapa orang tidak menunjukkan gejala apapun. Namun, pada orang-orang dengan komorbiditas, seperti usia tua, diabetes, dan lainnya kemungkinan besar mengalami sakit yang lebih serius seperti pneumonia, acute respiratory distress syndrome (ARDS), sepsis, dan disfungsi multiorgan yang dapat menimbulkan kematian (Singhal, 2020).

Berbagai himbauan dan edukasi telah berkalikali disampaikan oleh pemerintah, tenaga kesehatan, dan pihak-pihak yang berkaitan kepada masyarakat sebagai langkah pencegahan penularan. Namun demikian, masih terdapat pemahaman masyarakat yang kurang terhadap Covid-19. Selain itu masih banyak ditemukan pelanggaran seperti berpergian ke luar kota sehingga menimbulkan transmisi dari luar maupun lokal dalam suatu wilayah, seperti yang terjadi di Kabupaten Magelang.

Sampai bulan Juni ini, tedapat 142 kasus konfirmasi positif Covid-19 yang ditemukan di Kabupaten Magelang. 46 pasien masih di rawat, 92 pasien sembuh, dan 4 pasien meninggal. Jumlah pasien dengan pengawasan (PDP) sebanyak 41 pasien dan Orang Dengan Pengawasan (ODP) sejumlah 42 orang per 20 Juni 2020. Kabupaten Magelang terdiri atas 21 kecamatan, dan saat ini kasus positif Covid-19 paling banyak ditemukan di Kecamatan Secang. Kecamatan Grabag yang terletak berdekatan dengan Kecamatan Secang saat ini juga didapati 2 kasus terkonfirmasi positif Covid-19 (Pemerintah Kabupaten Magelang, 2020).

Pemerintahan Kecamatan Grabag sudah menerapkan kesadaran untuk melakukan tindakan preventif maupun promotif terhadap Covid-19. Namun, masih terdapat pula anggota masyarakat yang belum menerapkan anjuran dari pemerintah, termasuk warga masyarakat di wilayah RT 05/ RW 02, Kliwonan II, Kecamatan Grabag. Hal ini terjadi karena pengetahuan dan pemahaman masyakarat yang masih kurang mengenai Covid-19.

Kegiatan Pengabdian kepada Masyarakat ini merupakan implementasi Tri Dharma Perguruan Tinggi. Semua civitas akademika di perguruan tinggi diharapkan mampu berkontribusi langsung dalam upaya mitigasi Covid-19. Berdasarkan masalah yang terjadi, yaitu kurangnya pemahaman dan pengetahuan masyarakat serta kesadaran masyarakat untuk mencegah risiko penularan Covid-19 dan perilaku hidup bersih dan sehat (PHBS) yang belum sesuai dengan anjuran WHO, maka perlu dilaksanakan program kegiatan untuk membantu meningkatkan pengetahuan dan kesadaran masyarakat akan bahaya penularan Covid-19 serta tindakan promotif dan preventifnya termasuk perilaku hidup bersih dan sehat. Untuk itu kegiatan pengabdian kepada masyarakat ini mengambil tema "Suporting Pemahaman Masyarakat terhadap Covid-19" dengan tujuan untuk: (1) meningkatkan pengetahuan serta pemahaman khususnya masyarakat di wilayah RT 05/ RW 02, Kliwonan 2, Kecamatan Grabag mengenai bahaya dan penularan Covid-19, (2) meningkatkan kesadaran masyarakat mengenai tindakan promotif dan preventif sebagai upaya memutus mata rantai penularan Covid-19 melalui media edukasi secara daring dan tatap muka, (3) meningkatkan kesadaran masyarakat terhadap perilaku hidup bersih dan sehat (PHBS), terutama cuci tangan sesuai dengan anjuran WHO.

\section{METODE}

Kegiatan Pengabdian kepada masyarakat ini dilaksanakan mulai tanggal 1 Mei 2020 hingga 19 Juni 2020 di wilayah RT 05/RW 02, Kliwonan II, Grabag, Kabupaten Magelang yang terdiri atas 14 kepala keluarga dan pasien Klinik BPJS Anugrah. Kegiatan ini dilaksanakan dengan metode edukasi daring yang memanfaatkan media sosial sebagai sumber informasi, serta metode edukasi tatap muka dengan memperhatikan protokol kesehatan yang berlaku. Dalam kegiatan ini menggunakan teknik pendekatan masyarakat mezzo dan makro. Pendekatan masyarakat mezzo adalah pendekatan atau pembedayaan yang dilakukan terhadap sekelompok penerima manfaat, yaitu masyarakat RT 05/RW 02, Kliwonan II, Grabag, Magelang. Sedangkan pendekatan makro adalah pendekatan

$$
\text { Kesehatan }
$$


yang diarahkan pada suatu lingkungan yang lebih luas, yaitu pada pasien Klinik BPJS yang tidak hanya berasal dari lingkungan RT (Haris, 2014). Terdapat 7 program kegiatan yang dilaksanakan dalam kegiatan pengabdian kepada masyarakat, yaitu (1) sosialisasi melalui Whatsapp Group masyarakat, , (2) pembagian leaflet dan stiker tentang Covid-19 kepada masyarakat, (3) edukasi dan simulasi cuci tangan yang baik dan benar menurut anjuran WHO, (4) pemasangan poster langkah cuci tangan sesuai dengan anjuran WHO, (5) pembagian handsanitizer dan masker kepada masyarakat, (6) kerjasama dengan BPJS Kesehatan Kabupaten Magelang mengenai Skrining Mandiri Covid-19, (7) Sosialisasi melalui WhatsApp Group mengenai tindakan promotif dan preventif tentang Covid-19.

\section{HASIL DAN PEMBAHASAN}

Berdasarkan akumulasi kegiatan pengabdian kepada masyarakat yang telah dilaksanakan sesuai program kerja yang telah disusun, maka dapat disajikan hasil kegiatan beserta indikatornya sebagai berikut.

Tabel 1. Bentuk Kegiatan dan Indikator Keberhasilan

\begin{tabular}{|c|c|c|}
\hline No & Bentuk Kegiatan & Indikator Keberhasilan \\
\hline 1 & $\begin{array}{l}\text { Sosialisasi melalui } \\
\text { Whatsapp Group } \\
\text { masyarakat RT 05/RW } \\
\text { 02, Kliwonan II, } \\
\text { Grabag, Magelang } \\
\text { menggunakan media } \\
\text { berupa poster dan } \\
\text { penjelasan }\end{array}$ & $\begin{array}{l}\text { Meningkatnya } \\
\text { pemahaman masyarakat, } \\
\text { terdapat interaksi antara } \\
\text { pengabdi dan masyarakat } \\
\text { seperti diskusi tanya } \\
\text { jawab, dan tidak terdapat } \\
\text { pertambahan kasus } \\
\text { Covid-19 di lingkungan } \\
\text { RT }\end{array}$ \\
\hline 2 & $\begin{array}{l}\text { Pembagian leaflet dan } \\
\text { stiker kepada } \\
\text { masyarakat RT yang } \\
\text { berisi informasi } \\
\text { mengenai Covid-19 }\end{array}$ & $\begin{array}{l}\text { Meningkatnya } \\
\text { pemahaman masyarakat } \\
\text { terhadap bahaya dan } \\
\text { potensi penularan Covid- } \\
19\end{array}$ \\
\hline 3 & $\begin{array}{l}\text { Edukasi serta simulasi } \\
\text { cuci tangan yang baik } \\
\text { dan benar menurut } \\
\text { anjuran WHO } \\
\text { menggunakan media } \\
\text { handscoon dan cat } \\
\text { warna serta mengajak } \\
\text { masyarakat untuk ikut }\end{array}$ & $\begin{array}{l}\text { Masyarakat dapat } \\
\text { menerapkan cuci tangan } \\
\text { yang baik dan benar } \\
\text { menurut anjuran WHO, } \\
\text { adanya interaksi dan } \\
\text { ketertarikan masyarakat } \\
\text { saat sosialisasi dengan } \\
\text { meniru gerakan mencuci }\end{array}$ \\
\hline
\end{tabular}

serta dalam memeragakan cara cuci tangan yang benar

Pemasangan poster langkah cuci tangan sesuai dengan anjuran WHO di wilayah RT, klinik BPJS, dan tempat strategis lainnya

Pembagian handsanitizer dan masker kepada masyarakat

6 Kerjasama dengan BPJS Kesehatan Kabupaten Magelang mengenai Skrining Mandiri Covid-19 melalui aplikasi JKN Mobile kepada anggota BPJS dan masyarakat luas

$7 \quad$ Sosialisasi melalui WhatsApp Group mengenai tindakan promotif dan preventif kepada keluarga melalui media sosial tangan

Pemilik tempat pemasangan poster bersedia untuk dilakukan pemasangan poster dengan izin dari RT/RW, dan adanya ketertarikan masyarakat untuk membaca dan menerapkan anjuran dalam poster

\section{Meningkatkan kesadaran masyarakat dalam pemakaian masker dan penggunaan handsanitizer sebagai upaya pencegahan Covid-19}

\section{Masyarakat dapat menggunakan aplikasi JKN Mobile untuk skrining mandiri Covid- 19, serta dapat melakukan konsultasi online kepada dokter keluarga, minimal 3 pasien melakukan konsultasi online}

Keluarga memahami dan menerapkan tindakan promotif dan preventif terhadap Covid-19

\section{Sosialisasi melalui Whatsapp group masyarakat RT 05/RW 02, Kliwonan II menggunakan media berupa poster atau video}

Kegiatan sosialisasi ini dilaksanakan dengan metode daring menggunakan media sosial Whatssap Group masyarakat RT 05/RW 02, Kliwonan II, Grabag, Magelang. Sosialisasi ini bertujuan berdasarkan masalah kurangnya pemahaman dan pengetahuan masyarakat serta kesadaran masyarakat untuk mencegah risiko penularan Covid-19. Kurangnya pemahaman masyarakat ini dapat disebabkan karena masyarakat tidak mempertimbangkan mereka sedang dalam risiko penularan, menganggap remeh kondisi serius (misalnya disebutkan bahwa hanya Covid-19 hanya mengenai lansia dengan komorbiditas), atau tidak 
dapat melakukan tindakan preventif secara mandiri (Broucke, 2020). Media sosial digunakan karena mempunyai peran dalam edukasi kesehatan masyarakat yang memungkinkan individu untuk mempercepat penyebaran informasi terkait Covid19 (Sampurno, Kusumandyoko,dan Islam, 2020).

Materi yang diberikan pada sosialisasi adalah pemaparan mengenai Covid-19, transmisi, dan, pencegahannya seperti cuci tangan yang baik dan benar menurut anjuran WHO, memakai masker yang baik dan benar, serta edukasi berbelanja di era pandemi. Respons masyarakat pada sosialisasi cukup antusias dan terdapat diskusi tanya jawab, contohnya mengenai mode transmisi Covid-19 melalui hewan yang dikhawatirkan oleh masyarakat. Sosialisasi ini juga memperhatikan kultur dan demografi masyarakat desa.Pada kegiatan ini indikator keberhasilan telah tercapai, yaitu meningkatnya pemahaman masyarakat mengenai Covid-19, terdapat interaksi antara mahasiswa dan masyarakat seperti diskusi tanya jawab, poster disebarkan melalui media sosial ke masyarakat lain, serta tidak ditemukan kasus positif di wilayah RT 05/RW 02, Kliwonan II, Grabag, Magelang.

\section{Pembagian leaflet dan stiker kepada masyarakat RT yang berisi informasi mengenai Covid-19}

Pembagian leaflet dan stiker kepada masyarakat RT 05/RW 02, Kliwonan II, Grabag, Magelang dilaksanakan secara door-to-door bersama dengan pembagian handsanitizer dan masker. Leaflet yang diberikan merupakan informasi mengenai gejala dan tatalaksana Covid-19 yang berasal dari Satuan Gugus Penanganan Covid19 Kabupaten Magelang. Informasi ini digunakan agar masyarakat mengerti apabila mereka menemukan masyarakat sekitar yang memiliki gejala dan riwayat yang sesuai dengan Covid-19 dan dapat langsung menghubungi hotline center Corona Kabupaten Magelang. Sedangkan stiker yang dibagikan merupakan ajakan bagi masyarakat untuk selalu siaga, memakai masker, mencuci tangan, dan tetap dirumah apabila tidak ada kegiatan mendesak di luar rumah. Selain itu dilakukan pula edukasi mengenai penularan Covid19 pada media benda seperti uang di toko alat tulis, warung, dan apotek.

\section{Edukasi serta simulasi cuci tangan yang baik dan benar menurut WHO}

Cuci tangan merupakan salah satu tindakan pencegahan terhadap penularan Covid-19. Tingginya angka penularan Covid-19 salah satunya disebabkan karena kurangnya pengetahuan hand hygiene (kebersihan tangan) secara baik dan benar, sikap cuci tangan yang tidak baik, masyarakat mendapatkan informasi yang salah dari berita palsu, atau kurangnya dorongan kesadaran pentingnya cuci tangan (UNICEF, 2020). Oleh karena itu perlu dilakukan edukasi serta simulasi cuci tangan yang baik dan benar, yaitu sesuai dengan anjuran WHO dengan sasaran masyarakat yang datang ke Klinik BPJS Anugerah yang dilaksanakan dengan metode tatap muka dengan sasaran masyarakat Kecamatan Grabag yang berkunjung ke Klinik BPJS Anugrah. Edukasi cuci tangan juga dilaksanakan secara daring pada WhatsApp Group Prolanis Klinik Anugrah yang memiliki demografi masyarakat usia lanjut dengan komorbiditas seperti diabetes mellitus, hipertensi, dan sindrom metabolik. Edukasi dukasi tatap muka dilakukan dua kali dengan metode penyampaian yang berbeda dan jumlah audien 15-20 orang pada tiap pertemuan. Mayoritas pasien klinik belum mengetahui mengenai langkah-langkah cuci tangan yang direkomendasikan oleh WHO sehingga tidak efektif.

Pada edukasi pertama menggunakan media demonstrasi hanya berupa poster dan pertemuan kedua menggunakan media demonstrasi berupa poster, handscoon serta pewarna. Dari hasil pengamatan, didapatkan atensi yang lebih baik pada simulasi cuci tangan menggunakan handscoon dan pewarna. Masyarakat ikut mempraktikkan langkahlangkah cuci tangan yang baik dan benar menurut anjuran WHO. Hal ini sesuai dengan beberapa penelitian yang dilakukan dengan membandingkan media cetak dan demonstrasi sebagai metode demonstrasi bahwa metode demonstrasi lebih efektif karena masyarakat dapat menirukan langsung melalui gerakan psikomotor (Avissa, Nursalam and Ulfiana, 2015).

\section{Pemasangan Poster di Tempat Strategis}

Pemasangan poster dilakukan di tempattempat strategis seperti tempat perkumpulan warga 
RT 05/RW 02 Kliwonan II, Grabag, Magelang, Klinik BPJS Anugrah, dan toko-toko yang sering dikunjungi oleh masyarakat. Pemasangan ini disambut baik oleh masyarakat dan dari hasil laporan pengamatan penulis dan perangkat RT, masyarakat menjadi lebih paham serta waspada mengenai pencegahan penularan Covid-19.

\section{Pembagian Handsanitizer dan Masker kepada Masyarakat}

Pembagian handsanitizer dan masker dilakukan kepada masyarakat RT 05/RW 02, Kliwonan 2, Grabag, Magelang secara door-to-door dan pasien Klinik BPJS Anugerah saat sosialisasi cuci tangan berlangsung. Kegiatan ini bertujuan untuk mengajak masyarakat untuk senantiasa menggunakan masker dan mencuci tangan menggunakan handsanitizer saat berpergian. Dari hasil pengamatan saat pembagian masker dan handsanitizer, beberapa masyarakat yang berada di luar rumah yaitu 3 dari 14 kepala keluarga tidak menggunakan masker, juga terdapat kelompok masyarakat yang belum mengerti mengenai penggunaan handsanitizer. Oleh karena itu, pada pembagian handsanitizer dan masker ini juga dilakukan edukasi.

\section{Kerjasama dengan BPJS Kesehatan Kabupaten Magelang Mengenai Skrining Mandiri Covid-19 Melalui Aplikasi JKN Mobile \\ BPJS Kesehatan tengah meluncurkan menu} baru yaitu Skrining Mandiri Covid-19 di aplikasi JKN Mobile yang dapat diakses oleh anggota BPJS. Menu Skrining Mandiri Covid-19 berguna untuk menganalisis potensi risiko penyebaran Covid-19 yang berguna bagi fasilitas kesehatan setempat untuk melakukan tindakan promotif dan preventif. Selain itu, pada aplikasi JKN Mobile masyarakat juga dapat berkonsultasi secara online dengan dokter keluarga (BPJS, 2020). Sosialisasi ini ditujukan pada anggota BPJS dalam grup Prolanis dan masyarakat luas melalui instagram. Walaupun aplikasi Mobile JKN dan Menu Skrining Mandiri Covid-19 sangat interaktif dan user friendly, namun kerjasama ini tidak mencapai indikator keberhasilan karena sasaran masyarakat anggota BPJS yang tidak tepat karena sebagian besar masyarakat masih belum memahami teknologi terkini.

\section{Sosialisasi melalui WhatsApp Group Mengenai Tindakan Promotif dan Preventif kepada Keluarga}

Sosialisasi tindakan promotif dan preventif juga dilakukan melalui Whatsapp Group keluarga. Salah satu fungsi keluarga adalah fungsi perawatan atau pemeliharaan kesehatan yaitu keluarga berfungsi untuk mempertahankan keadaan kesehatan anggota keluarga (Friedman, 2020). Keluarga menjadi faktor yang sangat menentukan keberhasilan untuk membangun kebiasan baru di antara anggota keluarga (Gugus Tugas Percepatan Penanganan Covid-19, 2020). Pada sosialisasi ini didapatkan atensi keluarga untuk ikut menyebarkan informasi tindakan preventif dan promotif di luar lingkungan keluarga.

\section{KESIMPULAN}

Dari hasil kegiatan pengabdian kepada masyarakat yang telah dilaksanakan, maka dapat disimpulkan sebagai berikut:

1. Meningkatnya pengetahuan serta pemahaman khususnya masyarakat di wilayah RT $05 / \mathrm{RW}$ 02, Kliwonan II, Kecamatan Grabag mengenai bahaya dan penularan Covid-19.

2. Meningkatnya kesadaran masyarakat mengenai tindakan promotif dan preventif sebagai upaya memutus mata rantai penularan Covid-19 melalui media edukasi secara daring dan tatap muka,

3. Meningkatnya kesadaran masyarakat terhadap perilaku hidup bersih dan sehat (PHBS), terutama cuci tangan sesuai dengan anjuran WHO.

Implikasi dari hasil kegiatan pengabdian kepada masyarakat tersebut adalah berkembangnya jiwa kegotongroyongan dan kekeluargaan masyarakat di wilayah RT 05/ RW 02, Kliwonan II, Kecamatan Grabag, Kabupaten Magelang dalam menekan penularan Covid-19 di lingkungannya.

\section{UCAPAN TERIMAKASIH}

Ucapan terimakasih disampaikan kepada:

1. Univerasitas Sebelas Maret Surakarta, yang telah memberikan bantuan biaya Program Kerja kegiatan pengabdian kepada masyarakat sehingga kegiatan ini dapat terlaksana sesuai dengan tujuan yang direncanakan.

$$
\text { Kesehatan }
$$


2. Bapak Ketua RT dan Masyarakat di wilayah RT 05/ RW 02, Kliwonan II, Kecamatan Grabag, Kabupaten Magelang, yang telah berpartisipasi aktif pada kegiatan pengabdian kepada masyarakat ini sehingga dapat ikut serta dalam usaha menekan penularan dan penyebaran Covid-19 di lingkungannya.

\section{REFERENSI}

Avissa, F., Nursalam and Ulfiana, E. (2015) 'Efektivitas Pendidikan Kesehatan Metode Demonstrasi Dan Metode Ceramah Dengan Media Booklet Terhadap Perubahan Pengetahuan Dan Tindakan Mencuci Tangan Pada Anak Prasekolah', Jurnal Keperawatan Universitas Airlangga, pp. 113.

Badan Penyelenggara Jaminan Sosial (BPJS). (2020). Pengguna Mobile JKN Kini Bisa Screening Mandiri Gejala Covid-19 Langsung di Aplikasi.https://bpjskesehatan.go.id/bpjs/post/read/2 020/1512/Pengguna-Mobile-JKN-Kini-Bisa-

Screening-Mandiri-Gejala-Covid-19-Langsung-diAplikasi diakses pada 20 Juni 2020.

Friedman, M.M. (2010). Buku ajar keperawatan keluarga: riset, teori, \& praktik/ Marilyn M. Friedman, Vicky R, Bowden, Elaine G. Jones; Jakarta: EGC.

Gugus Tugas Percepatan Penanganan Covid-19. (2020). Edukasi Berbasis Keluarga Tularkan Kebiasaan Baru Cegah Covid-19 https://covid19.go.id/p/berita/edukasi-berbasiskeluarga-tularkan-kebiasaan-baru-cegah-covid-19 diakses pada 20 Juni 2020.

Haris, A. (2014) 'Memahami Pendekatan Pemberdayaan Masyarakat', Jupiter, XIII(2), p. 13.

Li, H., Liu, S. M., Yu, X. H., Tang, S. L., \& Tang, C. K. (2020). Coronavirus disease 2019 (Covid-19): current status and future perspectives. International journal of antimicrobial agents,
105951. Advance online publication. https://doi.org/10.1016/j.ijantimicag.2020.105951.

Pemerintah Kabupaten Magelang. (2020).

Kabupaten Magelang Tanggap Covid-19: Pusat Informasi Seputar Covid-19 di Kabupaten Magelang. https://infocorona.magelangkab.go.id diakses pada 9 Mei 2020.

Sampurno, M. B. T., Kusumandyoko, T. C. and Islam, M. A. (2020) 'Budaya Media Sosial, Edukasi Masyarakat, dan Pandemi Covid-19', SALAM: Jurnal Sosial dan Budaya Syar-i, 7(5). doi: 10.15408/sjsbs.v7i5.15210.

Singhal T. (2020). A Review of Coronavirus Disease-2019 (Covid-19). Indian journal of pediatrics, 87(4), 281-286. https://doi.org/10.1007/s12098-020-03263-6.

UNICEF (2020) 'Water, Sanitation and Hygiene ( WASH ) Covid-19 Response from Governments, Regulators and Utilities WASH Covid-19 Response', C/2/2020.

Van den Broucke S. (2020). Why health promotion matters to the Covid-19 pandemic, and vice versa. Health promotion international, 35(2), 181-186. https://doi.org/10.1093/heapro/daaa042.

World Health Organization. (2020). Coronavirus disease (COVID-19) Situation Report110.https://www.who.int/emergencies/diseases/nov el-coronavirus-2019/situation-reports diakses pada 9 Mei 2020. 